\title{
Theorizing Agri-Food Economies
}

\author{
Jan Douwe van der Ploeg* \\ College of Humanities and Development Studies (COHD), China Agricultural University (West Campus), \\ No.2 YuanMingYuan West Road, Haidian District, Beijing 100193, China
}

Academic Editor: Giaime Berti

Received: 23 June 2016; Accepted: 15 July 2016; Published: 22 July 2016

\begin{abstract}
This paper discusses agri-food economies and how they evolve over time. It also analyses how these economies, which often have contradictory dynamics, are theorized. A central thesis of the paper is that different theoretical representations not only reflect the differences in agro-economies and their developmental tendencies, but are also important drivers that actively shape the trajectories that they describe. The paper concludes by arguing that, more often than not, it is the newly emerging alternatives that are taking the initiative, responding to changing socio-economic demands while the hegemonic systems are merely reacting to the emerging alternatives. While it is possible that the alternatives might be appropriated and 'conventionalized' by the hegemonic systems, it is equally possible that the alternatives, especially when interconnected and rooted in democratic institutions, might induce a generalized crisis in the food systems that are currently dominant.
\end{abstract}

Keywords: food; agro-food economy; food system; co-production; crisis

\section{Nature and Society}

This text posits an agri-food economy as being located at the complex interface that exists between nature and society. The term 'nature' encompasses the eco-system and the natural resources it contains. 'Society' is the wider constellation in which the consumption of food (and other products and services produced by the agri-food economy) takes place. Agri-food economies, then, are the socio-technical systems that convert natural resources into food (and other useful products and services). Moreover, agri-food economies link nature and society. They do so in multiple and contrasting ways that depend on the nature of the resources utilized, the types of food and the relationships that prevail in society at large. The actors involved in primary production, food processing and distribution are key intermediaries in the conversion of natural resources into food, as are the institutional arrangements that govern their labour, their skills, their perception of nature and the way they relate with wider society. These factors all have a strong impact upon food and the ways in which it is produced, processed, distributed and consumed.

In synthesis: agri-food economies have three key constitutive elements: nature, society and the actors managing the interlinkages between the two. An agri-food economylinks natural resources to society at large, via the labour force and institutes that convert these resources into food. At the same time the agri-food system is crucially dependent on the reproduction of natural resources, the labour force and consumers wishing to buy and consume the food supplied. Agri-food economies not only produce food, they also, at the same time, reproduce the natural resources (and the eco-systems in which they are embedded), the labour force (and the institutional frameworks that regulate its availability and use) and the material and cultural patterns (and implied institutional frameworks) that govern the consumption of food. However, they do so in ways that can vary considerably. The reproduction of the constitutive elements takes different forms and this in turn feeds back into the production and the nature of food.

Over the ages the production of food has been primarily focused on securing its own reproduction (and thus its own autonomy and continuity). Natural resources are reproduced (and at the same time 
further developed) through farming. The same applies to those working in the production, processing and distribution of food: their lives, prospects, knowledge, etc., are reproduced in, and through, the farming activities (the self-provisioning of food being a strategic component), just as the main land-labour institutions are reproduced in and through the practice of farming. The relations with society at large are also reproduced—through e.g., the delivery of enough food of good quality which generates incomes and keeps society at large well nourished. Trust and recognition play a key role here. If there were no consumers wishing to buy the food and other products produced by a particular agri-food economy, such an economy would quickly come to a halt.

These systems of reproduction do not passively await the impact of the agri-food economies they support. Rather, they actively seek to shape these economies according to their own rationales. In terms of the natural resources and ecosystems with which they work the overriding priority is to maintain ecological balances, or to secure sustainability. When looking at wider society, rationales for enhancing quality, diversity and multiple securities come to the fore. These reflect the needs of those who are consuming the rural in one way or another. These needs are socially defined and will change over time and differ between places-just as the perception and definition of sustainability changes according to the eco-systems and the technological repertoire used to link with them. Finally, for those working in the agri-food economy, acceptable livelihoods are a non-negotiable objective (at least in the medium and longer term) which the agri-food economy must be able to satisfy. Consequently, the dynamics of agri-food economies are permanently being balanced and re-balanced: they are aligned with the rationales that shape the different reproductive domains. This balancing is particularly complicated since each domain is multi-layered: there are different levels (running from e.g., soil-biology, via landscapes and water-systems, to extended and interacting eco-systems) and each of these has its requirements and needs, just as it offers benefits (e.g., ecosystem services) that should not go unused.

Since reproductive fields differ from one place to another and from one period to another there is a huge variety in agri-food economies-the more so since the different balances might be set in different, even contrasting ways. Thus different agri-food economies can co-exist and co-evolve in the same spatial and temporal setting. The interrelations between them might be complementary but there might also be relations of displacement.

The reproductive fields discussed mean that agri-food economies are generally distinctive from economies in general. There are three distinctive features of agri-food economies that set them apart from other non-food economies. First, they are based on living nature (animals, crops, soil biology, pathogens, eco-systems, etc.). Thus, farming implies a double exchange: an ecological exchange and an economic one [1] and these two need to be balanced carefully. This double exchange means that farming cannot be seen as a simple extension of the general economy. This is even more the case when we take issues of sustainability and climate change into account. Dealing with living nature also requires appropriate institutional arrangements: in this respect the family farm and peasant agriculture have long been strategic. Second, agri-food economies deliver food, which is indispensable for the continuity and quality of human life. This again brings a series of particularities. Third, the conversion of natural resources into food requires both skills and decentralized loci of control. Farming cannot be (completely) standardized, quantified and planned. Because it deals with living nature there will be surprises, unexpected setbacks and newly emerging prospects that are, especially in the beginning, hard to recognize. Hence, the labour process, its efficiency and its development critically require (a) an organic unity of manual and mental labour; (b) a distribution of wealth that allows those doing the work to receive a proportionate share of the benefits; (c) a permanent process of trial and error, experimentation and learning that result in the acquisition of the skills needed. These requirements all point to the family farm as the main land-labour institution. Moreover, what applies to primary production has applied, for most of human history, to the processing, storage and distribution of food as well. Only with industrialization has this (partly) changed and this has had far reaching consequences for the nature and characteristics of food itself, as well as for the way it is prepared and 
consumed. These consequences have even contributed to a redefinition and reshaping of the actors involved in the acts of consumption.

\section{Contrasting Dynamics}

Over the last century, but especially since the 1960s, agri-food economies have been progressively disconnected from the constituting elements on which they had become solidly grounded through long historical processes [2]. Natural resources have been increasingly replaced by artificial growth factors and the last remaining (and indispensable) parts of nature (such as seeds and animals) are now being subjected to massive modification, in order to make them fit into completely re-defined (and materially industrialized) forms of primary production. This also applies to the processing, storage and distribution of food. The remaining remnants of 'nature' are eliminated (e.g., through pasteurization or micro-filtration) in order to obtain building blocks for food that no longer carries any traces of the place where, and the way in which, it was produced. Instead, at the level of distribution new images are constructed that no longer carry any relation with what went on beforehand. In terms of its relations with natural resources food has become virtual, and this also clearly affects its consumption and consumers.

The same applies to those involved in the production, processing and distribution of food. These processes are all increasingly independent of the skills, interests, prospects, knowledge and even the presence of involved actors. They do not matter much anymore (or do not matter at all). Moreover, in as far as they are needed, they have to operate according to scripts that meticulously prescribe what is to be done, how, when, where, in what sequence. Their work has been, as it were, expropriated by an external (and sometimes hardly visible) management. Since they do not matter much, they do not receive much. In the global south $70 \%$ of the poor (living on less than the proverbial 1 dollar a day) are rural, i.e., directly or indirectly dependent on agriculture. In the global north, large segments of the rural population endure poverty and see few prospects—although the size of these segments varies with the volatility of the markets.

Finally, agri-food economies have become disconnected (again: in a varying degree) from wider society. Those who consume food do not have the same impact on the agri-food economy as they did in the past. There are very few food markets that connect the production and consumption of food and which correct the former when those who consume want so. Instead, there are huge, often global systems for distribution (ironically called super markets) within which there is no room for negotiation or bargaining by consumers. In a super market it is 'take it or leave it'. At the same time competition within the value chain and between the large retail organizations means that a considerable part of the theoretically possible supply disappears. It is filtered out of the system, just as all living micro-elements are filtered out of our milk.

Thus agri-food economies have evolved into what now can best be referred to as food systems. The more so since they are no longer 'economies on their own'. They have become, as will be argued later, exchangeable elements in the global process of capital accumulation just as they are submitted to new, complex forms of corporate control [3]. New features have become dominant and the former distinctiveness has faded away. That is why I refer to the current food economies as food systems.

At the same time new agri-food economies are being constructed. Their nature, dynamics, reach and impact are, by now, well documented [4-9]. Rootedness (in recognizable natural resources and well-delineated eco-systems) and connectivity are key-words. The disconnections created by the now dominant food systems are being reconnected in these newly emerging agri-food economies, albeit on different levels and through all kinds of new mechanisms.

Thus we face, at the level of socio-technical reality, a richly chequered range of agro-food economies. Some are strongly rooted, others extremely disconnected and many represent in-between positions. Some evolve towards enlarged systemness, others go in contrasting directions. The levels of scale are highly diverse, as is the food being brought to the consumers. There is considerable heterogeneity. Even consumers themselves increasingly appear to exist within different 'tribes' 
and each of them is using food in order to make distinction; some consciously, others as an unintended consequence.

There are also differences in the ways in which agri-food economies are perceived, understood and represented, and these different perspectives interact in complex ways with the socio-technical heterogeneity discussed above.

\section{The Hegemonic Representation of Agri-Food Economies}

There are different ways to theoretically represent agri-food economies and these have far reaching consequences for the further development of these economies.

Today's sciences (especially the agricultural and food sciences) conceptualize agri-food economies (and their constituent elements) as being basically governed by markets and technology [10,11]. Technology defines the so-called 'functions of production', that are assumed to govern the conversion of inputs into outputs (at the farm level, but equally within food industries and in large retail outlets). These functions are represented as discrete S-shaped lines (or surfaces), on which each input level translates into a precise output level. If output levels fall below the S-shaped line or function, this points to failures by those involved in converting inputs into outputs. They are inefficient. With technological development, the functions move upwards and more output is possible with the same inputs-or a similar output might be realized with fewer inputs. The exact position of the agri-food enterprises on their respective S-shaped curves is, in turn, defined by the relations that reign in, and between, the different markets (consumer preferences and their reflection in price levels evidently being a crucial part of these markets). More precisely, it is the price-cost relation between inputs and output that specifies each singular optimum. Changes in market relations will induce a new optimum. Entrepreneurial capacities are needed to ensure that the optimum is repeatedly realized. In this way, markets and technology determine the dynamics of agri-food economies. Their 'behaviour' is essentially understood as the unfolding of the laws that govern the economy and the conversion of inputs into outputs (these latter include biological, chemical and physical laws). Markets and technology define how value is generated, how much and how this is distributed. The costs of using the markets and their relations to the costs associated with the management of the agri-food enterprises determine the organizational patterns (e.g., make or buy, take-over or compete) and the nature of the interrelations (hierarchical, co-operative, concentrated, dispersed, etc.) [12].

An important consequence of putting markets and technology centre stage is that the reproductive domains, their independent rationales and their own immanent requirements are marginalized [13-15]. They cannot have but a marginal, or at best an additional, role in the governance of agri-food systems. Another consequence is that agri-food economies are considered to be amenable to constant disruption and reshuffling. New technologies are introduced, markets change (for whatever reason), and reorganizations are needed time and again. At the same time such reorganizations are legitimized as an effect of technological development and/or market dynamics. They emerge as being right and justified in and by themselves. This is reflected in the subtle use of terms like 'new' and 'improved'. 'Improved potatoes' are presented as being, by definition, superior to existing cultivars and land races. Their superiority is supposed to be intrinsic. Their quality does not depend (anymore) on the judgement of farmers planting them or consumers eating them. 'Improved milk' (or in the case of micro-filtrated milk: 'improved storage life') is another example [16]. The term makes any critical inquiry into the nature of this 'improvement' redundant. There is no need to question it as the answer is already given. It is in the product provided.

In the current epoch the behaviour of enterprises is no longer related to existing market and price levels and available technologies; it is increasingly about expected market developments and expected technological developments [17]. The enterprises that locate themselves ahead of these developments are the ones that will win the lion's share of the inherent advantages, whilst the ones that are slower or that miscalculate will probably be outcompeted and become taken over as prey by their competitors. Thus, development becomes a battle for the future. Simultaneously, the economy (in this case the 
agri-food economy) is regarded as being not yet sufficiently developed, not yet applying the newest technological possibilities and not yet sufficiently entrepreneurial. Moreover, some time after these new possibilities are applied they themselves become outdated due to changing market relations and/or the availability of even newer technologies.

The emphasis on the new and the improved provided by the dominant approaches have a disruptive effect on the way that agri-food economies are. The same applies when they are to categorized as being not yet sufficiently modern (or whatever). In the dominant theories the production, processing and distribution of food are part of an ongoing process of modernization. This process is grounded in (and creates) a permanent disequilibrium. Food-economies as-they-ought-to-be (derived from the future and therefore supposed to be 'modern') systematically differ from agri-food economies as-they-are. The latter are at odds with new technological possibilities and economic opportunities which are the very features that drive the former. Agri-food economies as-they-ought-to-be make new technological possibilities and market opportunities come true. Moreover, this is not a one-off operation. It is ongoing: the reorganization into what ought-to-be is a constant feature-and views the agri-food economies as-they-are as inadequate, insufficient, outdated and unable to meet new demands. They need to be remade, to jump—time and again—into the future specified by interests of science and dominant economic forces.

It cannot be denied that the production of such disruptive images has triggered considerable dynamism. However, this comes at a significant price. Once the preferred future is superimposed on the 'inadequate' present, the structural disequilibrium translates into an array of societal and natural domains, and the consequences of this often have been disastrous. Modernization, which is meant to span the disequilibrium, has more often than not generated stress, low incomes, high risks, monotonous labour routines, solitude and the permanent threat of exclusion for those who work in agriculture. Equally it has brought nature into disarray, leading to natural resources being contaminated, biodiversity threatened and scenic landscapes destroyed [18]. Moreover, society as a whole is, in turn, confronted with often fatal food scandals and food scares and a significant decrease in the quality of life. What was assumed to be replaceable, has actually suffered strong, albeit highly varied processes of degradation.

The dialectics of paradigm and practices coincide with the logic of capital accumulation. Agriculture and the processing and distribution of food are not just a source for generating wealth that is centralized elsewhere. It is more: it is an economy where constantly growing flows of wealth are generated in order to feed processes of accumulation located elsewhere. This explains why modernization is not a one-off operation but a permanent process. Agriculture is permanently 'lagging behind' the needs of capital; therefore, it always needs to be 'modernized'. Capital's appetite is insatiable: the more it drains the countryside the hungrier it becomes.

Although it is rarely made explicit, the theories about the evolution of the food system view it is as a disruptive process-a chain of disruptions. Existing practices and their materializations need to be continuously replaced, and this process requires the introduction of ever-more artificial growth factors, technologies, energy, and re-fabricated food products. Thus capital eats its way deeper and deeper into agriculture, whilst simultaneously subordinating it ever more to its demands.

The dominant food systems are constantly draining the three reproductive fields discussed above. It is a one-way flow: the dominant food systems make no contribution to reconstituting these reproductive fields. Thus, the decisive reproductive fields are being hollowed out-and losing their relevance for the future of the production and consumption of food. This implies an economy of exploitation, and eventual exhaustion. Yet the dominant paradigm does not perceive or represent this as being damaging or regressive. On the contrary, it sees this as opening up new spaces for science, technology and capital. Once exhausted (or destroyed), the natural resources can be replaced by artificial growth factors; those who once did the work are made redundant and replaced by new technologies; and the relations with society at large are increasingly mediated by food industries and retail chains that construct images and symbols that suggest quality and safety. Thus, the dominant food economies 
devour their own foundations and replace them with new patterns of dependency that subordinate farming and the processing and consumption of food to financial, industrial and commercial capital. Ecosystems, peasantries and the synergy with society at large exit the stage and are replaced by capital, technology and marketing. Instead of reproducing the own foundations, the dominant agri-food economies consume them and then become dependent on new technological fixes, new organizational schemes and new inflows of capital.

The hegemonic views (the sciences included) not only reflect this basically extractive process (the impacts of which still cannot be assessed fully) - They actively drive it. This is because the image of how-the-agri-food-economy-ought-to-be lies at their very core.

The ideological and socio-political strength of this view resides, I believe, in the seemingly incontestable claim it imposes on the future. This is also why, in hegemonic discourse, time and again the question is raised of how the world population in 2050 will be provided with sufficient food (this is a question that echoes the ones of previous generations: it is the banner raised whenever and wherever structural changes in the food system are thought to be needed). Dominant views justify the changes they propose in the here-and-now with a detour that critically involves the future.

The dominant paradigm decidedly takes an Archimedean point, one that is localized in the future. This is not the future understood as unfurling the wide range of potentialities that exist within today's realities (some of which are probably still unknown). It is a future specified by institutionalized science through the analysis and combination of new technological possibilities and expected market tendencies. Hence the interventionist and prescriptive nature of today's agricultural and food sciences. For sui generis reasons they know the future better than others and-Since this future denies today's reality-They must intervene and 'reset' food related realities (some even claim they have the moral obligation to do so). Of course, things might be seen differently. Attention could be focused on agri-food economies as-they-are and by doing so it will repeatedly encounter established tendencies that could be translated into new trajectories for further development [19-21]. The different realities (or 'food-scapes') are seen as a mix of an extended set of possible factors that may (or may not) be of relevance: these could be the natural endowments, demographic patterns, history, the main institutional arrangements (and especially the main land-labour institutions), town-countryside relations, culinary traditions, collective memory, diversity in labour objects, possibilities to experiment, the presence of novelties and the possibility to build upon them, work routines, new or rediscovered knowledge [22], traditions, or market constellations, etc. One never knows beforehand what cocktail of these many 'ingredients' will be relevant and important. Different trajectories for further unfolding (for the co-evolution of nature and society) are possible.

One consequence of the adaptation of the Archimedean point is that it completely reverses the normal relationships between past, present and future. It also stifles the development of agri-food economies. Since there is only one possible future, development becomes a unidirectional process and the policies and technologies designed to move the food system towards the specified future broach no deviation. They become a straightjacket within which any deviation is seen as a mistake, doomed to end in failure, and placing unnecessary obstacles on the path of development. Such deviations should be abandoned and shunned. As a result, processes of development become extremely selective. There are 'good' practices and there are 'bad' ones; there are 'modern' features and there are 'traditional' ones. By contrast, alternative paradigms allow for, and encourage, variety and differentiated development trajectories. They do not result in coercive policies (as does the Western one), but typically result in multiple spaces for manoeuvre that allow for different and often contrasting courses of action. Instead of being coercive, alternative agricultural and rural policies tend to be enabling [19].

This helps explain why dominant theories frequently result in the formulation and implementation of mega-projects [23] and alternative approaches in 'small works' [24]. 


\section{Contrasting Approaches}

The production, processing, distribution and consumption of food can also be theorized, in a completely different way, by focussing on that what the actors involved are actually doing. This also implies taking their interrelations into account. This perspective (that is shared in the wide range of studies in short food chains, nested markets, local systems, etc.) studies how the actors involved redefine themselves, their activities, their interrelations and how, in so doing, they reshape food and the way it is produced, processed, distributed and consumed. Thus the attention shifts from food systems as they ought-to-be (moving towards a predefined and fixed 'future') towards agri-food economies as they are, and the Archimedean point is replaced by a multitude of possible ways to unfold further.

As simple as this may sound, this methodological shift creates radical differences. By focussing on practices (as part of an organized flow of activities that unfold over time and which are conditioned by the circumstances under which farmers, processors, traders and consumers operate), actors and endogenous perspectives take centre stage [25]. This leads to solutions that differ radically from those brought forward by the market and technology-oriented paradigm.

The alternative approaches produce theories that are a reflection of reality. They are ever so many attempts to understand agri-food economies as they are and why they are the way they are. They also unlock explorations into the possibilities for further unfolding. While the hegemonic discourse centres on food systems that are not yet fully developed, the contrasting views compose their narratives around a different key word: already. The newly emerging agri-food economies are already tackling this or that problem; they are already changing; already contributing to increases in production, and so forth. In the hegemonic scientific approaches, the development of food systems is basically exogenous, in the alternative ones the diversified trajectories of agri-food economies are endogenous.

In theories that provide an alternative to the hegemonic views, markets are arenas instead of self-regulating and abstract systems. It is acknowledged that the same time-space location might contain different markets, each grounded in its own, distinctive socio-technical infrastructure. Enterprises are not thought as simply following the 'logic of the market'-instead, they can partly shape and re-shape the markets through the ways they operate (and impact upon other markets). The possibility of different technological packages (and fixes) is recognized. Above all, these alternative approaches put the reproductive fields centre stage again, just as they include agency, i.e., the human capacity to understand and effectively change particular agri-food systems.

\section{Structural Holes, Institutional Voids and Interstices}

It goes without saying that the two approaches and the associated bodies of literature discussed so far are closely connected to the contrasting agri-food economies that exist in real life. Each approach reflects a particular practice, just as it carries the associated practice forward in a way that is not only distinct but, to a degree, unique as well. Both are partial theories ('middle ground theories' as old fashioned sociologists would have it) that relate to partial realities that co-exist with each other (albeit in a somewhat uncomfortable way).

It is remarkable (and regrettable, I would argue) that both approaches basically limit their research programme to their 'own' and 'favoured' reality. The hegemonic approach studies the dominant food systems (and are barely conceptually equipped to deal with the 'deviations' that occur at their 'periphery'). The alternative theories study the newly emerging alternative agri-food systems and mostly refrain from critically probing into the dominant food systems (although this could provide important insights, especially into the fragility of the dominant systems).

It would be ludicrous, of course, to argue for an 'integration' of the two contrasting approaches: the grammars and foci differ far too much. Beyond that, they link to each other in a critical way. Although the issue of 'co-existence' will surely dominate the scientific agendas in the years to come, one should not forget that in practice these different agri-food economies often relate to each other in an antagonistic way [9]. 
Nonetheless, particular interconnections should be constructed. I will focus here on two such interconnections. The first is that it needs to be made clear how alternative agri-food economies are, time and again, materially triggered and driven forward by the dynamics of the dominant agri-food systems. If this interconnection is left unexplored, the theories on alternative agri-food economies will remain too subjectivist: as if the creation and further unfolding of new agri-food economies mainly depends on the willingness and perseverance of the actors involved. The second regards the relative strength of the two contrasting food economies.

Concerning the first interconnection I will argue that structural holes, institutional voids and/or interstices are strategic concepts that might help to understand why the dominant food systems repeatedly give birth to new agri-food economies that are constructed in defiance of the dominant ones. A structural hole is, as it were, the counter-image of social relations. A structural hole is the lack of social relations [26]. It is "a buffer, like an insulator in an electronic circuit" p. 28 [26]. It is a set of disconnected elements (be they actors, activities, products, services, places, economic sectors, value circuits, technologies, or whatever), whose disconnection is intimately interwoven with ('caused by') the mechanics of the existing structure (or reigning patterns of socio-material relations). The current processes of globalization and de-regulation have produced ranges of such structural holes-generally, but specifically in the food systems as well. "Defining one's market too narrowly" p. 59 [27], opting for "skimming prices" or "follow-the-leader strategies" pp. 67, 68 [27] can all result in structural holes. The framing of food, the enlargement of value chains (both geographically and economically), a fear of renewal, a re-ordering of the social organization of time and space (that enlarge distances) and/or voracious competition that pushes quality products out of the market all have similar effects.

The key point is that such structural holes can be bridged. The newly emerging agri-food economies are the outcome of this bridging, they represent bridges that connect hitherto separated parts of the world. The more that the dominant food systems expand (an expansion that necessarily occurs through creating disconnections), the more space and need there is for new agri-food systems to emerge. This applies to new agri-food economies as a whole, but also to new nested markets, new products and services, and particularly new modalities of production, processing and distribution.

Bridging creates value and triggers economic growth [28]. Burt emphasized this by introducing the notion of the tertius gaudens. "The tertius establishes new negotiational relations; he extracts value and he adds value, strengthening the relations for later profit". Consequently, the tertius gaudens is "an entrepreneur in the literal sense of the word-A person who generates profit from being between others" p. 34 [28]. The tertius gaudens goes where others don't go. Structural holes are entrepreneurial opportunities for the tertius. By bridging them the tertius creates competitive advantage.

Institutional voids [29] might play a similar role. The concept refers to fields that are, as yet, not (or not fully) regulated. This points to the possibility to 'jump in' and to develop new products, new services, new institutional arrangements, new relations between consumers and producers, new socio-material infrastructures and more. These novel elements can be the starting points that develop into new agri-food systems. Within the dominant food systems renewal (the development, testing, and implementation of innovations) is extremely costly. Ironically, at the periphery novelty production is far easier and requires far fewer financial resources [30,31], whilst direct involvement makes for trajectories that are shorter and more agile (partly because of learning by doing) [32].

Interstices [33] are points, places, spaces where the dominant systems stop functioning smoothly. As such they represent ruptures in standardized routines. They are places where frictions and contradictions emerge, where accidents take place. Interstices are incidents. Dioxine in food is an example here. The outbreak of animal diseases (such as Mad Cow Disease, SARS, Foot and Mouth, etc.) also represent such incidents. Just as the non-acceptance of stamping out is a crack in the system. Interstices are the locations where people start to get uneasy, or upset: where critiques emerge and, especially, where alternatives are wrought. Interstices, therefore, are also sources from where new agri-food economies emerge or already existing agri-food economies are supported and strengthened. 
Structural holes, institutional voids and interstices might partly or wholly overlap, and may flow into each other. Analytically they are different as they refer to different aspects of what mostly is one, but many-sided, phenomenon. The first aspect regards the absence of value flows, the second describes the insecurity associated with this (indicating that a structural hole is, in a way, a 'no-go zone) and the third makes it clear that all this irks and irritates. Sometime one aspect dominates, sometimes another but when all three are present, there is a potential for new bridges to be constructed.

\section{Inducing a Crisis}

Once new agri-food economies are constructed, their mere existence raises the second issue: how do they relate to the dominant food systems?

Building on the work of Williamson [34,35], Saccomandi [29] developed a theoretical framework that links different types of market (spot market, quasi-market, hybrid forms, quasi organization and hierarchy) to illustrate the polyphormism of governance forms, which flow into each other according to a "cycle of organizational innovation". This approach shows how new, nested markets might evolve and become the general food markets of tomorrow, or more generally: how new agri-food economies may evolve into the dominant food systems of the future. Milone and Ventura, two former students of Saccomandi, have applied this perspective in an impressive range of empirical studies [36-40]. One important aspect of their work is that it highlights that the evolving agri-food economies do not end up as mere copies of the previously dominant food systems. There are considerable differences in regard to the geographical distribution of agri-economic activities, the number of people involved, the amount and distribution of the value added, the quality of the products and services and the ecological, social and economic sustainability of the newly created constellations. This is often due to important differences in the created socio-material infrastructures.

When trying to locate all this in a wider socio-political context, the first observation evidently is that it is not 'capital' (as represented by the dominant food systems) that is taking the lead here. Time and again it is the alternative agri-food economies that are taking the initiative. The initiative here clearly is with the 'otherness' of capital: with the involved consumers, farmers, small traders, students, social activists, in short 'labour' [41]. It is true that parts of what they create might be taken over by capital, and become conventionalized as new building blocks of the dominant food systems, as has happened with some organic markets. However, when these take-overs do occur they are followed by new designs coming from the 'labour side' that generates a next generation of agri-food economies. This reflects and affirms, as it were, Saccomandi's "cycle of organizational innovation".

It is important to note that take-over and conventionalization are only possible for a part of the newly developed images, practices, products, trade patterns and networks. Only the part that is controllable (which implies that it needs to be quantifiable, measurable, and predictable) will be expropriated. Furthermore, one should not assume the need for high skilled (and therefore expensive) labour. The conventionalized systems are to be operated and managed by low quality labour and be appropriate for scaling-up and large scale production as well. All this explains why conventionalization can only regard a part of the newly emerging agri-food economies.

To this we can add another factor: new agri-food economies are increasingly being structured in such a way that they cannot be taken over anymore. This is because their very existence is part of, and feeds into, learning processes. Food movements (as they are increasingly referred to) are learning, they have witnessed previous rounds of take-overs and subsequent conventionalization and thus construct new agri-food economies in such a way that they cannot be taken-over nor easily be outcompeted $[42,43]$. Avoiding potential take-overs mostly occurs through partly or wholly patterning the new alternatives as common pool resources [44]. A nested market, for instance, is nobody's property. It is commonly owned by (a flexible group of) producers and consumers that together compose this market. It is a common pool resource $[45,46]$. As such it is not for sale. It cannot be sold. Nor can it be taken over. The same also applies to network based agri-food economies. 
New agri-food economies are also not easily outcompeted. This is simply because the qualities they produce cannot be imitated [47] and/or the resource-base on which they are built (ecological and social capital rather than financial capital) and the by-passes they entail allow for prices lower than those required to interest the dominant food systems. New agri-food economies are often more effective and/or efficient [48] than the dominant food systems and it is not too adventurous to assume that, with further learning, these differences in effectiveness and efficiency will grow.

Finally, I have to refer to the overall balance of actual value flows. It is undoubtedly true that even in those places where agri-food economies are relatively strongly developed, their share of total turnover remains, as yet, modest. The point, however, is that what is taken by the tertio gaudens is no longer available for feeding the process of capital accumulation of, and in, the dominant food systems. Thus, the growth of agri-food economies does not simply take place alongside the dominant systems-it implies a slow-down of the accumulation of capital in the dominant food systems and under the reigning conditions (and especially in view of the high degree of financialization) this will translate into growing degrees of crisis. At the same time, it applies that the Chinese food economy clearly shows that small units of production might very will supply large cities and metropolis with enough food-provided that the socio-material interlinkages are the right ones especially chapter 10 [49].

With the seemingly unavoidable occurrence of new food-related incidents, with the emergence of new interstices, and the creation and subsequent discovery of new and more structural holes and institutional voids (further globalization and deregulation as proposed in new free trade agreements will undoubtedly create more such holes, voids and interstices). Abrupt shifts in the different but interlinked value flows can well be expected. This implies that further development will take place in certain systems, whilst others will be beset by crises. Thus, the key question is whether the new agri-food economies will be ready to deal with such changing relations when they do occur. If these new agri-food economies are interconnected horizontally, strongly rooted in the region and governed in democratic ways, the answer might be positive.

Conflicts of Interest: The author declares no conflict of interest.

\section{References}

1. Toledo, V. The ecological rationality of peasant production. In Agroecology and Small Farm Development; Altieri, M., Hecht, S., Eds.; CRC Press: Ann Arbor, MI, USA, 1990.

2. Van der Ploeg, J.D. Agricultural production in crisis. In Handbook of Rural Studies; Cloke, P., Marsden, T., Mooney, P., Eds.; Sage: London, UK, 2006; pp. 258-276.

3. Vitali, S.; Glattfelder, J.B.; Batiston, S. The Network of Global Corporate Control. PLoS ONE 2011, 6, e25995. [CrossRef] [PubMed]

4. Scettri, R. Novita in Campagna; IREF: Rome, Italy, 2001.

5. Anderson, E.; Gatignon, H. Firms and the Creation of New Markets. In Handbook of New Institutional Economics; Ménard, C., Shirley, M.M., Eds.; Springer: Dordrecht, The Netherlands, 2005; pp. 401-431.

6. USDA (United States Department of Agriculture). Farmers' Market Growth: 1994-2006, Agricultural Marketing Service; USDA: Washington, DC, USA, 2009.

7. Vecchio, R. European and United States farmers' markets: Similarities, differences and potential developments. In Proceedings of the paper presented at the 113th EAAE Seminar A resilient European Food Industry and Food Chain in a Challenging World, Chania, Greece, 3-6 September 2009.

8. Arfini, F.; Giovanni, B.; Andrea, M. Prodotti tipici e Denominazioni Geografiche, strumenti di tutela e valorizzazione; Gruppo 2013 Quaderni Eizioni Tellus: Rome, Italy, 2010.

9. Van der Ploeg, J.D. Newly emerging, nested markets: A theoretical introduction, In Rural Development and the Construction of New Markets; Hebinck, P., van der Ploeg, J.D., Schneider, S., Eds.; Routledge: London, UK; New York, NY, USA, 2015; pp. 16-40.

10. Van der Ploeg, J.D. The Virtual Farmer: Past, Present and Future of the Dutch Peasantry; Royal van Gorcum: Assen, The Netherlands, 2003. 
11. Scrinis, G. Nutritionism: The Science and Politics of Dietary Advice; Columbia University Press: New York, NY, USA, 2013.

12. Saccomandi, V. Agricultural Market Economics: A Neo-Institutional Analysis of Exchange, Circulation and Distribution of Agricultural Products; Royal van Gorcum: Assen, The Netherlands, 1998.

13. Van der Ploeg, J.D. Potatoes and knowledge. In An Anthropological Critique of Development: The Growth of Ignorance; Hobart, M., Ed.; Routledge: London, UK, 1993.

14. Sumberg, J.; Thompson, J.; Woodhouse, P. Why agronomy in the developing world has become contentious. Agric. Hum. Values 2012. [CrossRef]

15. Sumberg, J., Thompson, J., Eds.; Contested Agronomy, Agricultural Research in a Changing World; Routledge: New York, NY, USA; London, UK, 2012.

16. Van der Ploeg, J.D.; Benvenuti, B.; Bussi, E.; Losi, G.; Piagnagnoli, C.; de Roest, C. Latte vivo: Il Lungo Viaggio del Latte dai Campi alla Tavola-Prospettive Dopo il Parmacrack; Diabasis: Reggio Emilia, Italy, 2004.

17. Van der Ploeg, J.D. The New Peasantries: Struggles for Autonomy and Sustainability in an Era of Empire and Globalization; Earthscan: London, UK, 2008.

18. Marsden, T. The Condition of Rural Sustainability; Royal van Gorcum: Assen, The Netherlands, 2003.

19. De Schutter, O. The transformative potential of the right to food. In Report of the Special Rapporteur on the Right to Food; United Nations, General Assembly: New York, NY, USA, 2014.

20. iPES FOOD (International Panel of Experts on Sustainable Food Systems). From Uniformity to Diversity, A Paradigm Shift from Industrial Agriculture to Diversified Agroecological Systems. 2015. Available online: www.ipes-food.org (accessed on 20 May 2016).

21. Van der Ploeg, J.D. Peasants and the Art of Farming: A Chayanovian Manifesto; Fernwood Publishing: Halifax, NS, Canada; Winnipeg, MB, Canada, 2013.

22. Altieri, M.A. Agro-Ecology and Small Farm Development; CRC Press: Ann Arbor, MI, USA, 1990.

23. Scott, J.C. Seeing Like a State: How Certain Schemes to Improve the Human Condition have Failed; Yale University Press: London, UK, 1998.

24. Donaldson, J.A. Small Works: Poverty and Economic Development in South-Western China; Cornell University Press: Ithaca, NY, USA; London, UK, 2011.

25. Long, N. Activities, Actants and Actors: Theoretical Perspectives on Development Practice and Practitioners. In Constructing a New Framework for Rural Development; Research in Rural Sociology and Development; Milone, P., Ventura, F., Ye, J., Eds.; Emerald: Bingley, UK, 2015; Volume 22, pp. 31-58.

26. Burt, R.S. Structural Holes: The Social Structure of Competition; Harvard University: Cambridge, MA, USA, 1992.

27. Willard, G.E.; Savara, A.M. Patterns of Entry: Pathways to New markets. Calif. Manag. Rev. 1988, 30, 57-76. [CrossRef]

28. Barth, F. Economic Spheres in Darfur. In Themes in Economic Anthropology; Firth, R.R., Ed.; Tavistock: London, UK, 1967.

29. Hajer, M. Policy without polity? Policy analysis and institutional void. Policy Sci. 2003, 36, $175-195$. [CrossRef]

30. Osti, G. Gli Innovatori Della Periferia, la Figura Sociale Dell'innovatore Nell'Agricoltura di Montagna; Reverdito Edizioni: Torino, Italy, 1991.

31. Wiskerke, J.S.C., van der Ploeg, J.D., Eds.; Seeds of Transition. Essays on Novelty Production, Niches and Regimes in Agriculture; Royal van Gorcum: Assen, The Netherlands, 2004.

32. Oostindie, H.; van Broekhuizen, R. The dynamics of production. In Unfolding Webs: The Dynamics of Regional Rural Development; van der Ploeg, J.D., Marsden, T., Eds.; Royal van Gorcum: Assen, The Netherlands, 2008; pp. 68-86.

33. Holloway, J. Crack Capitalism; Pluto Press: London, UK, 2010.

34. Williamson, O. Markets and Hierarchies: Analysis and Complications; The Free Press: New York, NY, USA, 1975.

35. Williamson, O. The Economic Institutions of Capitalism; The Free Press: New York, NY, USA, 1985.

36. Ventura, F. Organizzarsi per Sopravvivere: Un Analisi Neo-Istituzionale Dello Sviluppo Endogeno Nell'agricoltura Umbra. Ph.D. Thesis, Wageningen University, Wageningen, The Netherlands, 2001.

37. Ventura, F.; Milone, P. Innovatività Contadina e Sviluppo Rurale: Un'analisi Neo-Istitutionale del Cambiamento in Agricoltura in tre Regioni del Sud Italia; Franco Angeli: Milano, Italy, 2005. 
38. Ventura, F.; Milone, P. Traiettorie di Sviluppo: Il Sostegno a Modelli di Sviluppo Endogeno: Dall'esperienza del Distretto Viti-vinicolo di Montefalco alla Valorizzazione Dell'area della Valnerina; CESAR: Assisi, Italy, 2005.

39. Ventura, F.; Milone, P. I Contadini del Terzo Millennio; Franco Angeli: Milano, Italy, 2007.

40. Milone, P.; Ventura, F. The visible hand in building new markets for rural economies. In Rural Development and the Construction of New Markets; Hebinck, P., van der Ploeg, J.D., Schneider, S., Eds.; Routledge: London, UK; New York, NY, USA, 2015; pp. 41-60.

41. Cleaver, H. Reading Capital Politically; Anti/Theses: Leeds, UK, 2000.

42. Schneider, S.; Niederle, P. Resistance strategies and diversification of rural livelihoods: The construction of autonomy among Brazilian family farmers. J. Peasant Stud. 2010, 37, 379-405. [CrossRef]

43. Radomsky, G.; Niederle, P.; Schneider, S. Participatory systems of certification and alternative marketing networks: The case of the Ecovida Agroecology Network in South Brazil. In Rural Development and the Construction of New Markets; Hebinck, P., van der Ploeg, J.D., Schneider, S., Eds.; Routledge: London, UK; New York, NY, USA, 2015; pp. 79-98.

44. Ostrom, E. Governing the Commons: The Evolution of Institutions for Collective Action; Cambridge University Press: New York, NY, USA, 1990.

45. Polman, N.; Poppe, K.J.; van der Schans, J.-W.; van der Ploeg, J.D. Nested markets with common pool resources in multifunctional agriculture. Riv. di Economia Agrar. 2010, LXV, 295-318.

46. Van der Ploeg, J.D.; Ye, J.Z.; Schneider, S. Rural development through the construction of new, nested markets: Comparative perspectives from China, Brazil and the European Union. J. Peasant Stud. 2012, 39, 133-173. [CrossRef]

47. Ventura, F.; van der Meulen, H. La Costruzione della Qualita: Produzione, Commercializzazione e Consumo della Carne Bovina in Umbria; CESAR: Assisi, Italy, 1994.

48. North, D.C. Government and the cost of exchange in history. J. Econ. Hist. 1984, 44, 255-264. [CrossRef]

49. Van der Ploeg, J.D.; Ye, J.Z. China's Peasant Agriculture and Rural Society: Changing Paradigms of Farming; Routledge: Oxon, UK; New York, NY, USA, 2016.

(C) 2016 by the author; licensee MDPI, Basel, Switzerland. This article is an open access article distributed under the terms and conditions of the Creative Commons Attribution (CC-BY) license (http://creativecommons.org/licenses/by/4.0/). 